\title{
Foresight jako koncepcja wspomagająca rozwój regionalny
}

Hubert Pachciarek | Uniwersytet Szczeciński | h.pachciarek@wneiz.pl

Dr Aleksandra Rudawska | Uniwersytet Szczeciński | aleksandra.rudawska@gmail.com

| Abstrakt

Cel

Celem artykułu jest weryfikacja przydatności koncepcji foresight w kreowaniu warunków sprzyjających rozwojowi społeczno-gospodarczemu regionu ze szczególnym uwzględnieniem województwa zachodniopomorskiego.

\section{Metodologia}

Odnosząc się do doświadczeń japońskich i europejskich z zakresu stosowania foresightu, autorzy dokonali oceny efektów wdrożenia programu w województwie zachodniopomorskim $w$ wymiarze rezultatów zarówno „twardych” (w postaci raportów i wiedzy z zakresu technologii), jak i „miękkich” (dotyczących podstawowych wartości), które okazały się najważniejszymi efektami stosowania koncepcji. Ponadto dokonano zestawienia warunków rozwoju społeczno-gospodarczego regionu oraz przeanalizowano oczekiwania liderów środowiskowych zamieszkujących na terenie województwa zachodniopomorskiego $\mathrm{w}$ zakresie kształtowania warunków sprzyjających poczuciu odpowiedzialności i zaangażowania się na rzecz regionu. Materiał badawczy został zgromadzony podczas spotkania grupy fokusowej oraz uzupełniony wynikami badania sondażowego. 


\section{Wnioski}

Na podstawie analizy porównawczej uzyskanych wyników dotyczących oczekiwań liderów środowiskowych i efektów stosowania koncepcji foresight stwierdzono, że jest to pożądana forma wspierania rozwoju Pomorza Zachodniego.

\section{Oryginalność}

Oryginalność artykułu polega na odniesieniu wieloletnich doświadczeń japońskich z zakresu stosowania metody foresight i uzyskanych w ten sposób rezultatów do potrzeb społeczno-gospodarczych regionu zdefiniowanych podczas dyskusji fokusowej liderów różnych środowisk zawodowych regionu Pomorza Zachodniego. W ten sposób autorzy wskazali na potencjał zastosowania foresightu nie tylko do określania kierunków rozwoju polityki innowacyjności na poziomie regionalnym, lecz również w celu wspierania kształtowania warunków społeczno-gospodarczych rozwoju regionalnego.

\section{JEL: R58}

\section{Wprowadzenie}

Współczesny system społeczno-gospodarczy opiera się na konkurencji nie tylko między podmiotami gry rynkowej, tj. przedstawicielami trzech sektorów gospodarki (organizacje gospodarcze, organizacje pozarządowe oraz jednostki administracji publicznej), lecz również podejmuje konkurencję z innymi systemami. W tym znaczeniu konkurencja przebiega zarówno w ramach regionów, jak i między regionami. Z tego względu regiony traktowane są obecnie jako podmioty zarządzania, również na poziomie strategicznym, co oznacza konieczność wykorzystania dostępnych zasobów ludzkich, materialnych oraz wiedzy na rzecz kształtowania rozwoju społecznogospodarczego na poziomie regionalnym.

Konkurencyjność regionu oznacza „przewagę nad innymi regionami będącą wypadkową atrakcyjności oferty usługowej kierowanej do obecnych i potencjalnych użytkowników regionu, którymi są mieszkańcy, firmy, inwestorzy, goście. Jej źródłem jest nowoczesna infrastruktura materialna, instytucjonalna i intelektualna regionu” (Stawasz 2004: 203). Konkurencyjność regionalna oznacza tworzenie warunków życia dla mieszkańców, warunków funkcjonowania dla przedsiębiorców oraz kreowanie wizerunku miejsca sprzyjającego inwestorom zewnętrznym oraz potencjalnym mieszkańcom. Powiązanie tych elementów wymusza oparcie zarządzania regionami na innowacyjności i elastyczności podejścia do oczekiwań i potrzeb interesariuszy regionalnych. Proces zarządzania regionami musi być realizowany nie tylko w sensie operacyj- 
nym, lecz także w odniesieniu do perspektywy strategicznej. Należy zatem generować sprzyjające warunki w następujących aspektach:

- administracyjno-prawnych, wynikających z uwarunkowań zewnętrznych (ustawodawstwo i prawodawstwo narzucane z zewnątrz) oraz wewnętrznych (efektywność i przychylność urzędnicza, mierzona czasem potrzebnym na wydanie decyzji administracyjnych czy też otwartością w rozwiązywaniu problemów);

- badawczo-rozwojowych, związanych ze współpracą między różnymi uczestnikami życia społeczno-gospodarczego oraz środowiskiem naukowo-badawczym. Zakorzenienie środowiska akademickiego w regionie oznacza nie tylko dostęp do wiedzy, lecz również umożliwia kształtowanie kadr dla regionalnej gospodarki oraz pełni funkcję kulturotwórczą;

- ekonomicznych, wynikających z dostępnych zasobów materialnych i niematerialnych, wypracowanych przez poprzednie pokolenia oraz współczesnych mieszkańców;

- społecznych, oznaczających gotowość do pracy na rzecz wspólnego dobra;

- kulturowych, oznaczających poziom utożsamienia się mieszkańców z „małą ojczyzną” i przywiązania do tradycji. Każdorazowo pomaga to w kształtowaniu wizerunku regionu na zewnątrz i ułatwia promocję wobec partnerów.

W kontekście zarządzania regionem w perspektywie strategicznej kluczowe wydaje się poznanie oczekiwań interesariuszy regionalnych. Powinna bowiem zachodzić dwukierunkowa zależność, w której działalność i aktywność interesariuszy regionalnych powinny przekładać się na rozwój regionu, ten z kolei powinien umożliwiać ukształtowanie warunków zapewniających długotrwałe sukcesy wszystkim mieszkańcom i organizacjom regionu (Borodako 2009: 123).

\section{Podstawy rozwoju społeczno-gospodarczego regionów}

Wraz z rozwojem polityki regionalnej oraz w związku z ukierunkowaniem strumieni finansowych pochodzących z budżetów centralnych oraz funduszy zewnętrznych (funduszy strukturalnych UE) na regiony wytworzono sytuację, w której rozwój gospodarczy państwa w coraz większym stopniu kreowany jest na poziomie regionalnym. Ponadto dostrzega się istotną zależność między dobrobytem społeczeństwa a poziomem rozwoju regionalnego. Samo pojęcie „rozwój” oznacza sekwencję przemian w wymiarze zarówno ilościowym, jak i jakościowym, co w wymiarze gospodarczym oznaczać będzie wzrost poziomu konkurencyjności podmiotów gospodarki regionalnej oraz regionu jako takiego, a w wymiarze społecznym - wzrost poziomu życia mieszkańców w sferach ekonomicznej, społecznej i kulturowej. Należy zauważyć, iż definicje rozwoju regionalnego według różnych autorów są zbieżne i opierają się na dwóch aspektach: poziomie życia mieszkańców oraz konkurencyjności gospodarki. Dlatego też autorzy niniejszego opracowania przyjmują, za T. Kudłaczem, że rozwój regionalny to trwały wzrost poziomu życia mieszkańców i potencjału gospodarczego w skali określonej jednostki terytorialnej (Kudłacz 1999: 15). Rozwój jest więc rozumiany przez pryzmat jego komponentów, w tym potencjału 
i struktury gospodarczej, środowiska naturalnego, infrastruktury regionalnej i ładu przestrzennego oraz poziomu życia mieszkańców. Tę listę powinno się uzupełnić o integrację społeczną i tożsamość kulturową jako komponenty rozwojowe o charakterze „miękkim”, które warunkują podstawy rozwoju społeczno-gospodarczego. Należy bowiem zauważyć, iż kreowanie rozwoju regionalnego, tj. podnoszenie dobrobytu mieszkańców oraz poprawa warunków funkcjonowania podmiotów gospodarczych, musi przebiegać równolegle w wymiarze gospodarczym i społecznokulturowym. Stanowi to bowiem warunek trwałego rozwoju, w sensie ilościowym i jakościowym, poziomu życia mieszkańców, a także umożliwia tworzenie atrakcyjnego wizerunku dla potencjalnych inwestorów zewnętrznych.

Warto wspomnieć, że czynnikiem rozwoju społeczno-gospodarczego regionu jest współpraca interesariuszy regionalnych - zarówno na poziomie jednostkowym, tj. pomiędzy przedsiębiorstwami lub organizacjami, ugrupowaniami gospodarczymi (np. zgodnie z teorią gron lub w ramach łańcuchów gospodarczych), jak i na poziomie regionalnym w odniesieniu do władz regionalnych i przedstawicieli środowisk zawodowych.

Podsumowując powyższe rozważania: kreowanie warunków rozwoju społeczno-gospodarczego opiera się na wdrażaniu na poziomie regionu licznych inicjatyw: „miękkich” - o charakterze społeczno-kulturowym oraz „twardych” - inwestycyjnych. Inicjatywy te mogą być podejmowane oddolnie i bazować na pracy oraz działalności liderów regionalnych różnych podmiotów komercyjnych czy też non profit, lub odgórnie, gdzie inicjatorem są przedstawiciele władz regionalnych. Każdorazowo sukces poszczególnych projektów uzależniony jest jednak od spełnienia następujących warunków:

- budowa koalicji interesariuszy reprezentujących różne środowiska społeczne lub gospodarcze w ramach ugrupowania; każde przedsięwzięcie wymaga bowiem porozumienia na różnych płaszczyznach: gospodarczej, społecznej, politycznej itp.,

- integracja przedstawicieli interesariuszy wokół wspólnego celu podejmowanych przedsięwzięć,

- budowa sprawnego centrum zarządzania procesem realizacji inicjatywy, koordynującego zaangażowanie poszczególnych interesariuszy,

- realizacja wszystkich funkcji zarządzania, czyli planowania, organizowania, motywowania i kontrolowania, umożliwiających skuteczne i ekonomiczne wdrożenie przedsięwzięcia.

Warunkami dobrej współpracy między interesariuszami są natomiast przede wszystkim: wzajemna zgodność celów partnerów, komplementarność działań, pozytywne znaczenie dla partnerów osiągania wspólnych celów, wspólna realizacja zadań cząstkowych, dobrowolność współpracy (swoboda wstąpienia i wystąpienia), formalność bądź nieformalność, zachowanie ekonomicznej i prawnej samodzielności uczestniczących partnerów (Bembenek 2006: 34). Jest to droga kreowania trwałych relacji między interesariuszami, które umożliwiają współpracę na poziomie regionalnym, a tym samym dynamizują proces rozwoju regionalnego, czyli ulepszają warunki funkcjonowania przedsiębiorstw, a w konsekwencji podnoszą poziom życia mieszkań- 
ców. Dlatego też kluczowe dla rozwoju regionalnego staje się efektywne zarządzanie inicjatywami i projektami na poziomie regionalnym, przy zaangażowaniu do ich realizacji szerokiego grona przedstawicieli różnych grup zawodowych, tj. liderów środowisk lokalnych.

Ze względu na złożoność problemu dynamizacji rozwoju społeczno-gospodarczego na poziomie regionalnym oraz kształtowania konkurencyjności regionalnej konieczne wydaje się efektywne zarządzanie na poziomie regionu. Zarządzanie to musi mieć wymiar zarówno operacyjny, taktyczny, jak i strategiczny. Natomiast ukierunkowanie inicjatyw oddolnych oraz podejmowanie optymalnych decyzji co do inicjatyw odgórnych wymaga ustalenia kierunków rozwoju regionu. Rozwój regionu zależy zatem od efektywności zarządzania strategicznego, rozumianego w kategoriach „specyficznej filozofii władz regionalnych i interesariuszy w regionie - opisującej jego stan obecny, a jednocześnie wytyczającej kierunki rozwoju i główne sposoby postępowania" (Bodorako 2009: 129). Proces zarządzania strategicznego regionem nie powinien być więc traktowany jako właściwość urzędników najwyższego szczebla administracji samorządowej, lecz jako przestrzeń porozumienia i partycypacji przedstawicieli wszystkich interesariuszy regionalnych. W rozważaniach na temat regionów należy odnosić się do uwarunkowań zarówno wewnętrznych, jak i zewnętrznych. Region, będąc spójną całością, jest jednocześnie elementem większej całości. Znaczenie dla rozwoju regionalnego mają także decyzje podejmowane zewnętrznie względem władz regionalnych oraz polityka realizowana na poziomie krajowym i europejskim. Natomiast decyzje podejmowane w ramach procesu zarządzania strategicznego w regionie znajdują swoje istotne implikacje nie tylko dla podmiotów regionalnych. Mają wpływ również na funkcjonowanie regionów sąsiednich oraz na politykę zewnętrzną, realizowaną na poziomie krajowym. Jest to kluczowa przesłanka do otwarcia procesów kształtowania strategii regionalnych na interesariuszy regionalnych, a warunki dobrej współpracy i potrzeba realizacji inicjatyw ułatwiających dynamizację rozwoju społeczno-gospodarczego sprzyjają podniesieniu znaczenia ich partycypacji oraz dają możliwość większego wpływu na ostatecznie podejmowane decyzje. Należy pamiętać, że tak jak w przypadku zarządzania strategicznego na poziomie przedsiębiorstw, tak też w przypadku regionów podstawą jest planowanie strategiczne, ukierunkowane na budowanie wspólnej wizji przyszłości stanowiącej konsensus interesariuszy regionalnych oraz wynikających z niej strategicznych kierunków rozwoju. Planowanie strategiczne ma charakter badawczy i analityczny w odniesieniu do eksploracji uwarunkowań wewnętrznych i zewnętrznych regionu oraz antycypacyjny w odniesieniu do ustalania celów rozwoju i sposobów ich realizacji.

Współcześnie władze regionalne mogą korzystać z koncepcji zarządzania wspierających realizację działań ukierunkowanych na podnoszenie konkurencyjności regionalnych i dynamizujących rozwój społeczno-gospodarczy. Jest to istotne w odniesieniu do złożoności problematyki zarządzania oraz dynamiki zmian zachodzących w otoczeniu. Jedną z koncepcji zyskujących na znaczeniu, coraz bardziej popularnych w Polsce, jest foresight. Pytaniem badawczym postawionym w ramach niniejszego artykułu jest kwestia, czy foresight może wpływać pozytywnie na rozwój społeczno-gospodarczy regionu oraz czy jest potrzebny w obecnych uwarunkowaniach województwa zachodniopomorskiego. 


\section{Foresight jako koncepcja wspierająca rozwój społeczno-gospodarczy na poziomie regionalnym}

„Foresight to systematyczny, przyszłościowy sposób ciągłego doskonalenia współpracy międzyśrodowiskowej w celu budowania wspólnej średnio- lub długookresowej wizji rozwojowej, jej kierunków i priorytetów, a w tym kontekście podejmowanie bieżących decyzji i mobilizowanie wspólnych działań” (Lozano et al. 2009: 209). Foresight bardzo często tłumaczony jest jako przewidywanie (Jasiński 2007: 1) i tak też jest traktowany jako koncepcja służąca prognozowaniu przyszłości. W rzeczywistości jednak służy przede wszystkim budowaniu wizji przyszłości, tworzeniu warunków współpracy pomiędzy interesariuszami oraz mobilizowaniu przyszłych działań w celu kształtowania warunków przyszłości. Jest to istotna różnica, przejawiająca się w procesie realizacji programów foresight, co wypływa wprost z zaprezentowanej definicji. Różnica pomiędzy przewidywaniem a kształtowaniem przyszłości wynika przede wszystkim z funkcji, jaką koncepcja ta zaczęła pełnić, niejako przy okazji. Pierwsze procesy foresight zostały uruchomione w celu określenia technologii przyszłości, kiedy to borykający się z trudnościami gospodarczymi Japończycy po zakończeniu II wojny światowej postanowili inwestować w rozwój technologii. Finansowanie z ograniczonego budżetu nieograniczonych wręcz potrzeb inwestycyjnych w rozwój różnych technologii nie było jednak możliwe w długim okresie. Postanowiono więc uruchomić proces foresight, którego nadrzędnym celem było zdefiniowanie tych sektorów technologicznych, które w przyszłości będą stanowić o sile japońskiej gospodarki. Japończycy bazowali na metodzie delfickiej, rozsyłając kwestionariusz ankietowy do kilku tysięcy ekspertów. Uzyskane w ten sposób informacje pozwoliły na ustalenie priorytetów odnośnie do tych dziedzin nauki i technologii, które będą miały największe znaczenie w przyszłości. Od tamtej pory do dnia dzisiejszego procedura ta jest powtarzana w cyklu pięcioletnim. Najistotniejszy w tym kontekście jest jednak fakt, że bardzo szybko liderzy projektu zorientowali się, iż wcale nie najważniejsze są „twarde” rezultaty procesu w postaci raportów i rekomendacji dotyczących finansowania rozwoju nauki i technologii. Kluczowe okazały się te efekty, które dzisiaj nazywa się modelem „4k+z”, czyli: komunikacja, koncentracja na przyszłości, koordynacja, konsensus i zaangażowanie (Foresight technologiczny, tom 1 2005: 9-10).

Oznacza to, że najważniejszą wartością dodaną ze stosowania programów foresight jest to, co nazywa się zwyczajowo kulturą kooperacji, czyli zespołem norm i wartości, które ukierunkowują interesariuszy na budowanie relacji w swoim otoczeniu, zachęcają do współdziałania oraz motywują do poszukiwania wspólnych celów i interesów z innymi interesariuszami. Zgodnie z powyższym zasadnicze rezultaty stosowania koncepcji foresight idą w dwóch kierunkach. Pierwszym jest tworzenie warunków współdziałania liderów różnych środowisk zawodowych w celu uzyskania konsensusu w zakresie wspólnej wizji przyszłości poprzez zaangażowanie uczestników procesu, do którego prowadzi wzajemna komunikacja. Drugim natomiast jest kreowanie kultury myślenia o przyszłości i w tym kontekście podejmowania bieżących działań, co znajduje swoje odzwierciedlenie w istocie koncepcji, czyli kształtowaniu przyszłych warunków funkcjonowania podmiotów uczestniczących w procesie foresight. Elementem łączącym jest koordynacja, czyli proces zarządzania inicjatywami foresight, który umożliwia uzyskanie zało- 
żonych rezultatów twardych i miękkich. Należy zatem zauważyć, że foresight ma na celu kształtowanie warunków przyszłości w miejsce jej przewidywania. Dlatego też koncepcja ta może być bardzo użyteczna w odniesieniu do zarządzania strategicznego na poziomie regionu.

Foresight jest realizowany w trzyetapowym cyklu, który został zaprezentowany na rysunku 1.

\section{Rysunek 1 | Cykl realizacji procesu foresight}

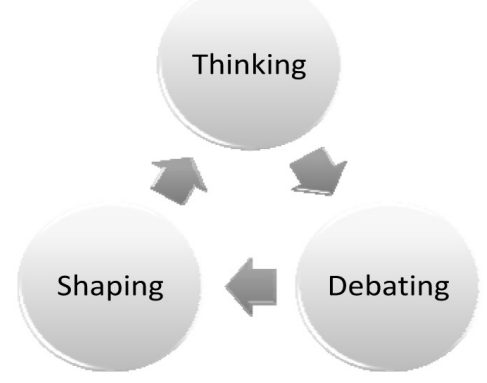

Źródło: opracowanie własne na podstawie: http://cordis.europa.eu/foresight/definition.htm.

Cykl realizacji programów foresight składa się z trzech etapów powtarzających się sekwencyjnie przez cały okres realizacji programu. Pierwszy etap - przemyślenie uwarunkowań podejmowanego problemu (thinking) - realizowany jest indywidualnie przez uczestników programu. Na tym etapie analizowane są zarówno bieżące, jak i przyszłe warunki danego zagadnienia. Tym samym rozważaniom podlegają różne scenariusze przyszłości. Po zakończeniu pierwszego etapu następuje konfrontacja wniosków prezentowanych przez różnych uczestników. W ramach drugiego etapu przeprowadzana jest debata oparta na otwartej wymianie argumentów (debating), której celem jest poszerzanie horyzontów myślowych i weryfikacja indywidualnych założeń uczestników. Realizowany proces komunikacji jest podstawą do kształtowania konsensusu w postaci wspólnej wizji przyszłości i ukierunkowuje uczestników na wspólne dobro. Ostatni etap stanowi kształtowanie warunków przyszłości poprzez inicjowanie procesów decyzyjnych i wspieranie w tym zakresie decydentów, podejmowanie wspólnych inicjatyw o charakterze rozwojowym i wspieranie liderów już zainicjowanych przedsięwzięć (shaping). W ten sposób możliwe jest oddziaływanie na kształt polityki regionalnej, a przez to na poziom konkurencyjności i dynamizację rozwoju społeczno-gospodarczego.

Program foresight nie musi mieć zdefiniowanego czasu zakończenia. Przykład japoński wskazuje na możliwość cyklicznego realizowania procesu, co znajduje odzwierciedlenie w skuteczności koncepcji, gdyż uzyskanie dwóch najważniejszych efektów programu, czyli kultury współdziałania i myślenia o przyszłości, wymaga czasu.

Foresight może mieć zastosowanie również jako koncepcja koordynacji aktywności interesariuszy, ukierunkowując ich na wspólne cele. Ponadto foresight może następująco oddziaływać na realizowaną politykę regionalną: (Da Costa, Warnke, Cagnin, Scapolo 2008: 373-376): 
- dostarczanie informacji istotnych z punktu widzenia podejmowania decyzji w postaci scenariuszy przyszłości prezentujących szanse i zagrożenia oraz rekomendacje do podejmowanych decyzji;

- ułatwianie wdrożenia polityki poprzez integrację liderów środowiskowych w ramach procesu foresight, m.in. przez tworzenie instrumentów komunikacji w celu budowania konsensusu kształtuje się jednocześnie platformę interesariuszy, świadomych wagi dobra wspólnego i gotowych do przyjęcia pozycji liderów wdrażanych zmian;

- zapewnienie wyższego poziomu akceptacji dla wdrażanych zmian dzięki angażowaniu w ramach foresightu szerokiego spektrum przedstawicieli różnych grup zawodowych i reprezentacji pełnego wachlarza oczekiwań i potrzeb społecznych w procesie kształtowania polityki;

- przełożenie języka polityki na język zrozumiały społecznie, dlatego foresight może być traktowany jako narzędzie komunikowania społeczeństwu decyzji o wdrażanych zmianach wraz z ich uzasadnieniem;

- rekomendowanie i oddziaływanie na zmiany w systemie politycznym ze względu na potrzebę adaptacji do otoczenia i zachowania odpowiedniego poziomu elastyczności polityki dzięki łączeniu w ramach foresight decydentów z przedstawicielami społeczeństwa oraz zacieśnianiu więzi pomiędzy różnymi poziomami decyzyjnymi systemu politycznego.

Podkreślając znaczenie foresightu w kształtowaniu warunków rozwoju społeczno-gospodarczego regionów, warto posłużyć się wnioskami przygotowanymi przez ekspertów High Level Export Group (Kaleta, Moszkowicz 2006: 12-13):

- decyzje uwzględniające efekty działań w ramach programu foresight wydają się lepsze, gdyż rosnąca złożoność systemu społeczno-gospodarczego wymusza, aby decyzje były podejmowane na bazie wiarygodnych prognoz oraz wdrażane przy zachowaniu społecznego konsensusu;

- foresight może stanowić unikatowy strategiczny wkład interesariuszy do myślenia o przyszłości i rozwijać zdolności adaptacyjne oraz gotowość do zmian, bowiem ukierunkowanie foresight na kreowanie warunków kształtowania kultury współdziałania oraz kultury myślenia o przyszłości powoduje wzrost elastyczności i adaptacyjności systemu polityki regionalnej;

- wartość foresightu wyraża się zarówno w procesie, jak i w stworzonych produktach, co stanowi odzwierciedlenie koncepcji „4k+z”.

\section{Studium przypadku Narodowego Programu Foresight w Japonii}

Koncepcja foresight została stworzona na potrzeby armii jeszcze w trakcie II wojny światowej, a po wojnie znalazła swoje zastosowanie w przemyśle w Stanach Zjednoczonych. Pod koniec lat 60. wraz z transferem rozwiązań technicznych i organizacyjnych z USA do Japonii przeniesiono również metodę budowania scenariuszy przyszłości w przemyśle. W konsekwencji w Japonii 
uruchomiono serię programów foresightu technologicznego, przy czym Narodowy Program Foresightu wciąż trwa i jest realizowany w 5-letnich cyklach (Kuciński 2010: 3).

W ramach japońskiej metodyki wdrożenia foresightu technologicznego wyróżniono cztery poziomy wdrożenia i przypisano im instytucje odpowiedzialne za program na danym poziomie (tabela 1).

Tabela 1 | Struktura Narodowego Programu Foresight w Japonii

\begin{tabular}{|l|l|}
\multicolumn{1}{|c|}{ Poziom wdrożenia } & \multicolumn{1}{c|}{ Instytucje wdrażające foresight } \\
\hline Holistyczny & Agencja Nauki i Technologii (Science and Technology Agency) \\
\hline Poziom makro & Ministerstwa \\
\hline Poziom mezo & Ugrupowania przedsiębiorców \\
\hline Poziom mikro & Pojedyncze przedsiębiorstwa i instytucje badawcze \\
\hline
\end{tabular}

Źródło: opracowanie własne na podstawie Kuwahara (2002: 127).

Agencja Nauki i Technologii rozpoczęła przygotowania do pierwszego programu foresight już w 1969 r. Program ten został oparty na metodzie delfickiej, stanowiącej podstawę programów foresight realizowanych na całym świecie. Do głównych celów stosowania foresightu technologicznego w Japonii zalicza się identyfikację głównych trendów technologicznych w przyszłości oraz określenie priorytetowych w perspektywie strategicznej dziedzin nauki i technologii (Cuhls 2001: 559). Założeniami Narodowego Programu Foresight w Japonii było zaangażowanie możliwie dużej liczby ekspertów, ciągła realizacja programu w cyklu 5-letnim oraz przygotowywanie scenariuszy w perspektywie 30 lat. Do dzisiaj przeprowadzonych zostało osiem rund badań delfickich. Szczegóły ilościowe omawianego programu foresight prezentuje tabela 2.

Tabela 2 | Zmiany ilościowe w programie foresightu technologicznego realizowanego przez Science and Technology Agency

\begin{tabular}{|c|c|c|c|c|c|}
\hline Runda & Data realizacji & $\begin{array}{c}\text { Liczba } \\
\text { technologii }\end{array}$ & Liczba tematów & $\begin{array}{c}\text { Okres } \\
\text { przewidywań }\end{array}$ & $\begin{array}{c}\text { Liczba } \\
\text { odpowiedzi }\end{array}$ \\
\hline 1 & $1970-1971$ & 5 & 644 & $1971-2000$ & 2482 \\
\hline 2 & 1976 & 7 & 656 & $1976-2005$ & 1316 \\
\hline 3 & $1981-1982$ & 13 & 800 & $1981-2010$ & 1727 \\
\hline 4 & 1986 & 17 & 1071 & $1986-2015$ & 2007 \\
\hline 5 & 1991 & 16 & 1149 & $1991-2020$ & 2385 \\
\hline 7 & $1995-1996$ & 14 & 1072 & $1996-2025$ & 3586 \\
\hline 8 & $1999-2000$ & 16 & 1065 & $2001-2030$ & 3106 \\
\hline 9 & $2003-2004$ & 13 & 858 & $2006-2035$ & 2239 \\
\hline
\end{tabular}

Źródło: opracowanie własne na podstawie: T. Kuwahara (2002: 128), Yoda (2008) oraz The $9^{\text {th }}$ Delphi Survey (Summary). The $9^{\text {th }}$ Science and Technology Foresight-Contribution of Science and Technology to Future Society (2010). 
Struktura uczestników (respondentów) omawianego programu foresight kształtuje się następująco: około 50\% stanowią eksperci reprezentujący środowisko akademickie, ponad 30\% - reprezentujący biznes, $15 \%$ - reprezentujący administrację państwową, a resztę stanowią przedstawiciele organizacji pozarządowych. W programie reprezentowane są zatem wszystkie środowiska mające kluczowe znaczenie dla rozwoju społeczno-gospodarczego, co zapewnia możliwość komunikacji między wszystkimi interesariuszami.

Ważnym krokiem w realizacji Narodowego Programu Foresight w Japonii było jego umiędzynarodowienie od 5. tury badań, do której zaproszono specjalistów z Niemiec, a następnie innych państw, m.in. Francji i Korei. Stało się tak z obawy przed nadmierną orientacją japońską (zamknięciem) w przeprowadzanych badaniach. Wyniki uzyskiwane w ramach realizacji programu są wykorzystywane przede wszystkim do:

- planowania procesów badawczych, a także planowania działalności gospodarczej,

- określania priorytetów rozwoju określonych dziedzin technologii oraz analizowania średnioi długookresowych trendów rozwojowych,

- komunikowania wizji przyszłości i informacji niezbędnych w procesach planowania strategicznego; możliwe jest również uzyskanie konsensusu na temat kierunków rozwoju,

- ukierunkowania interesariuszy na myślenie o przyszłości oraz ich integracji wokół procesu kształtowania przyszłości przez podejmowanie bieżących decyzji,

- umożliwienia współpracy między interesariuszami ze względu na uświadomienie wspólnej wizji przyszłości i podjęcie wspólnych działań w tym kontekście,

- kształtowania polityki innowacyjności w odniesieniu do priorytetowych technologii i wypracowanych scenariuszy przyszłości.

Realizacja foresightu w Japonii na czterech poziomach (tabela 1) umożliwia kompleksowe podejście do kształtowania i realizacji polityki, zaangażowanie różnych interesariuszy, pozwala na efektywne sterowanie strumieniami finansowymi oraz na optymalizację stosowanych narzędzi wdrażania opracowanej polityki. Jednocześnie uczestnicy programu mogą kształtować swoją bieżącą działalność w odniesieniu do uzyskiwanych rezultatów. W ten sposób proces komunikacji realizowany za pomocą programu przynosi obopólne korzyści.

Drugim kamieniem milowym w rozwoju Narodowego programu Foresight w Japonii było dostrzeżenie, że postęp technologiczny nie rozwiązuje problemów społecznych, a wręcz je pogłębia. Dynamicznie rozwijającej się gospodarce japońskiej zaczęły towarzyszyć poważne problemy społeczne, takie jak problemy demograficzne i starzenie się społeczeństwa oraz problemy ekologiczne. Dlatego też od 6 tury Narodowego Programu Foresight zmieniono perspektywę badawczą z predykcji przyszłych scenariuszy rozwojowych różnych dziedzin nauki i technologii na poszukiwanie odpowiedzi na pytanie, w jakim zakresie postęp technologiczny odpowiada na zapotrzebowanie społeczne (Karube 2001: 222).

Zmiana perspektywy programu oznaczała również konieczność przedefiniowania celów foresightu. Dlatego też od 6. tury cele te przedstawiano jako po pierwsze określenie średnio-i długo- 
terminowych potrzeb społecznych, w tym weryfikacja, w jakim stopniu społeczeństwo korzysta z postępu technologicznego, po drugie wskazanie tych technologii, które w największym stopniu odpowiadają na potrzeby społeczne. Znalazło to swoje konsekwencje w 7. turze badawczej, gdy do badanych tematów wprowadzono również takie zagadnienia jak kultura, styl życia czy system podatkowy.

Narodowy Program Foresight w Japonii został uznany za jeden z najefektywniejszych, zarówno w perspektywie japońskiej, jak i międzynarodowej, a wpływ foresightu na prowadzoną politykę innowacyjną i naukową za bardzo ważny i skuteczny (Yoda 2008: 4). Wynikało to w dużej mierze z orientacji Japończyków na proces foresightu w miejsce nadmiernego przywiązywania wagi do samych rezultatów programu. Za kluczowy efekt programu uznano wykreowanie specyficznego ,języka” komunikacji, który dzięki zaangażowaniu ekspertów również spoza nauk ścisłych i z różnych grup interesariuszy stał się powszechnie zrozumiały.

Profesor Kuwahara, opierając się na przeprowadzonych badaniach, wskazuje, iż realizacja procesu foresight sama przez się prowadzi do wzrostu prawdopodobieństwa powodzenia realizowanych projektów badawczych ze względu na promowanie współpracy i bazowanie na konsensusie dotyczącym wspólnej wizji przyszłości. Wspomniany już w niniejszym artykule model „4k+z” pokazuje, że foresight prowadzi do wykreowania kluczowych wartości z punktu widzenia kształtowania warunków rozwoju społeczno-gospodarczego regionu. Budowanie wśród interesariuszy kultury współdziałania oraz kultury myślenia o przyszłości pozwala na zdefiniowanie konsensusu w postaci wspólnej wizji przyszłości oraz umożliwia zaangażowanie na rzecz jej realizacji przez podejmowanie wspólnych inicjatyw oraz wspieranie procesów decyzyjnych realizowanych przez władze regionalne. Dlatego też foresight umożliwia kreowanie przyszłości przez zaangażowanych interesariuszy, co znajduje potwierdzenie w raporcie przygotowanym dla Komisji Europejskiej przez High Level Expert Group. Przyszłość nie powinna być przewidywana, lecz społecznie kreowana, a foresight uznawany jest za służące do tego potencjalnie najefektywniejsze obecnie narzędzie (HLEG report 2002: 14).

W tym znaczeniu foresight to program łączący informacje dotyczące bieżących trendów i przyszłych zmian rozwojowych z informacjami uzyskiwanymi od uczestników programu i ich postawami. Ma to swoje następujące konsekwencje: predykcja przyszłości jest włączana w generowaną w ramach foresightu wspólną wizję przyszłości, a integracja interesariuszy na poziomie regionalnym i rozwój sieci współpracy między nimi jest równie ważny co końcowe produkty programów foresight w postaci wygenerowanej wiedzy i raportów (Sandkjaer Hanssen et al. 2009: 1735-1736). Aby zapewnić powodzenie procesu foresight, należy zatem uwzględnić pięć następujących elementów (Miles, Keenan 2002: 15):

- ustrukturyzowany proces projekcji i antycypacji długoterminowych trendów rozwojowych i potrzeb społecznych, gospodarczych i technologicznych,

- interakcyjne metody debaty, analizy i studiów nad potrzebami i trendami rozwojowymi, angażujące interesariuszy reprezentujących różne środowiska zawodowe, 
- podejście interakcyjne ukierunkowane na budowanie sieci współpracy pomiędzy interesariuszami,

- produktem programu foresightu powinny być nie tylko scenariusze przyszłości, lecz także omówienie wspólnej wizji przyszłości, na której może być budowany społeczny konsensus,

- klarowne określenie, w jaki sposób bieżące decyzje oddziałują na realizację wypracowanej wizji.

\section{Zapotrzebowanie na foresight w województwie zachodniopomorskim - wnioski z dyskusji podczas konferencji Czas na rozwój. Człowiek i biznes w społeczeństwie obywatelskim}

Podczas konferencji odbyło się spotkanie fokusowe poświęcone zagadnieniu odpowiedzialności jednostki za rozwój swojej „małej ojczyzny”, która na potrzeby dyskusji została zdefiniowana jako region, w którym żyjemy. Dyskusja dotyczyła województwa zachodniopomorskiego, uczestnicy pochodzili bowiem właśnie z tego regionu. Punktem wyjścia do dyskusji było postawienie pytania, czy jednostka może oddziaływać na rozwój swojego regionu oraz jakie warunki muszą być spełnione, aby było to możliwe. W dalszej części dyskusji podjęto również tematy związane z barierami zaangażowania się człowieka w rozwój jego regionu oraz zastanawiano się nad sposobami kształtowania warunków umożliwiających wsparcie liderów regionalnych oraz zaangażowania się szerszego grona mieszkańców na rzecz budowy własnej „małej ojczyzny”. W spotkaniu wzięło udział trzech przedstawicieli środowiska akademickiego, dwóch przedsiębiorców, przedstawiciel instytucji samorządowych oraz przedstawiciel wolnych zawodów. Tak zróżnicowane grono dyskutantów umożliwiło zaprezentowanie szerokiego spektrum opinii i przemyśleń na temat rozwoju społeczno-gospodarczego Pomorza Zachodniego oraz zaangażowania mieszkańców na rzecz dobra wspólnego. Mentorem dyskusji był prof. Antoni Kamiński.

Na wstępie dyskusji uczestnicy doszli do wspólnego wniosku, że człowiek może być odpowiedzialny za rozwój regionu, w którym żyje, pod warunkiem posiadania narzędzi oddziaływania na politykę realizowaną w regionie. Należy zauważyć, iż wybory demokratyczne władz regionalnych nie są pod tym względem wystarczające. Konieczne jest wdrożenie do funkcjonowania regionów narzędzi konsultacji społecznych i debat na tematy regionalne oraz zapewnienie dostępu do bieżącej informacji. Z drugiej jednak strony brak odpowiedzialności też może być wygodny dla mieszkańców, obniża bowiem oczekiwania względem samego siebie oraz regionu, w którym żyje. Brak świadomości dobra wspólnego, jakim jest otoczenie, zwalnia z aktywności na jego rzecz. Nie jest to pożądany stan rzeczy, gdyż uniemożliwia budowanie poczucia tożsamości regionalnej.

Do podstawowych warunków poczucia odpowiedzialności za region dyskutanci zaliczyli posiadanie wspólnych celów, motywacje wynikające ze świadomości wspólnego dobra oraz aktywność 
liderów regionalnych. Cele powinny natomiast posiadać wymiar idei zarówno w wymiarze globalnym, jak i lokalnym. Idea stanowi „ziarno”, które w konsekwencji przeradza się w inicjatywę, jednocząc przy tym ludzi wokół wspólnych wartości. Dlatego też strategia regionalna powinna opierać się raczej na wspólnych wartościach tworzących wizję przyszłości niż doraźnych celach i wspólnocie interesów, która ze swej natury jest krótkotrwała. Budowa wspólnej wizji na bazie idei regionalnych prowadzi do świadomości istnienia wspólnego dobra, jakim jest region, tym samym zachęcając mieszkańców do zaangażowania się na rzecz rozwoju swojej „małej ojczyzny”. Należy jednak zauważyć, że dobro wspólne to nie tylko wspólne idee, lecz także wspólne obowiązki i reguły, którym należy się podporządkować. Przykładem takich obowiązków jest chociażby obowiązek podatkowy.

Ponadto podjęto dyskusję na temat odpowiedzialności wspólnoty za jednostkę. Czy tylko jednostka odpowiada za rozwój swojej „,małej ojczyzny”, czy też wspólnota ma zobowiązania względem jednostki? Poczucie dobra wspólnego oraz budowanie wspólnej wizji przyszłości oznacza odpowiedzialność nie tylko za siebie, lecz również za otoczenie. Jest to zatem relacja dwustronna. Wspólnota w równym stopniu odpowiada za jednostkę.

Zauważono, że wiele sukcesów w wymiarze regionalnym, które miały miejsce w ostatnim czasie, miało charakter oddolny. Przykładami takich sukcesów jest powstanie Akademii Sztuki w Szczecinie oraz powszechne zaangażowanie mieszkańców i szerokie zainteresowanie ubieganiem się Szczecina o miano Europejskiej Stolicy Kultury 2016. Mimo że w tym drugim przypadku sukcesem nie jest zwycięstwo w konkursie, to istotne znaczenie dla regionu miał sam proces ubiegania się o to miano. Stwierdzono, iż w Szczecinie od wielu lat żadna idea nie przyciągnęła zaangażowania tak wielu osób jednocześnie. Charakterystyczne w obu przypadkach jest jednak to, że pomysły na realizację obu przedsięwzięć wyszły od liderów regionalnych, aktywnych w swoich środowiskach, którzy w odpowiednim momencie uzyskali wsparcie różnych środowisk. Dopiero w drugiej kolejności nastąpił proces instytucjonalizacji przedsięwzięć.

Uczestnicy spotkania doszli do konsensusu, iż większe efekty mobilizacji społecznej mają te inicjatywy, które początkowo powstają nieformalnie z inicjatywy lokalnych liderów. Inicjatywy odgórne, narzucone przez władze regionalne, pomimo większego zaplecza instytucjonalnego, często nie angażują społeczności i nie wytwarzają poczucia wspólnoty interesu. Wnioskiem z zaobserwowanego zjawiska jest konieczność współpracy pomiędzy instytucjami samorządowymi a liderami lokalnymi, niezależnie od miejsca powstania inicjatywy. Z jednej strony urzędnicy powinni wykazywać się otwartością i zrozumieniem dla inicjatyw społecznych, z drugiej zaś powinni pozyskiwać wsparcie liderów na rzecz inicjowanych przez siebie przedsięwzięć. Warunkiem koniecznym rozwoju regionalnego jest zatem kształtowanie liderów regionalnych zdolnych do realizacji i koordynacji przedsięwzięć o charakterze regionalnym.

Jednostka będzie miała poczucie odpowiedzialności za rozwój regionu przy spełnieniu omówionych powyżej warunków. Jednak aby kształtować te warunki, konieczny jest proces edukacji oparty na podejściu podmiotowym. Głównym celem edukacji powinno być wypracowanie 
w uczniach umiejętności pracy zespołowej i uświadomienie im, iż ludzie nie są samowystarczalni, lecz wzajemnie się uzupełniają. Ponadto niezbędna jest komunikacja na poziomie regionalnym, której celem powinno być rozeznanie potrzeb społecznych oraz wytworzenie poczucia wspólnoty. Istotna jest w tym rola mediów, których zadaniem powinno być kształtowanie pożądanych postaw społecznych ukierunkowanych na rzecz rozwoju społeczno-gospodarczego regionu.

Do najważniejszych barier poczucia odpowiedzialności za swoją „małą ojczyznę” dyskutanci zaliczyli:

- dezintegrację ludzi i instytucji - brak komunikacji i współpracy pomiędzy władzami regionalnymi a liderami środowiskowymi,

- brak poczucia tożsamości regionalnej i dumy - zgodnie z opinią jednego z uczestników człowiek dumny jest skłonny do działania zadaniowego, brak poczucia dumy prowadzi do działań obronnych, w tym również przez wycofanie,

- nieuwzględnianie przez władze regionalne inicjatyw oddolnych i brak wsparcia dla liderów tych inicjatyw,

- oparcie się na wspólnocie interesów, która daje tylko krótki efekt zaangażowania w miejsce oparcia na ideach i poszukiwaniu wspólnej wizji przyszłości.

Oprócz spotkania fokusowego wszyscy uczestnicy konferencji wzięli udział w badaniu ankietowym. Autorzy artykułu zadali pytanie o uszeregowanie według ważności tych cech społeczności, które mają największe znaczenie w kontekście zaangażowania na rzecz rozwoju regionalnego tak, że cecha najważniejsza otrzymywała 5 pkt, a piąta pod względem ważności 1 (lista cech była szersza niż 5 pozycji). 94\% możliwych do zdobycia punktów (możliwa do zdobycia liczba punktów oznacza, iż każdy respondent wskazałby daną cechę jako najważniejszą) uzyskały aktywność społeczna i gospodarcza mieszkańców, 65\% zdolność do współpracy. Ponadto wysoki wynik uzyskały następujące odpowiedzi: zdolność myślenia o przyszłości (43\%), poczucie tożsamości lokalnej (41\%). Stanowi to potwierdzenie wniosków z dyskusji fokusowej oraz odzwierciedla elementy modelu „,k+z”.

\section{| Zakończenie}

Rozwój regionu jest wypadkową wielu sił, wśród których coraz większego znaczenia nabiera rola społeczności i jednostek. Problemem okazuje się jednak zbyt niski poziom współpracy władz z mieszkańcami oraz niezadowalający poziom zaangażowania, odpowiedzialności oraz aktywności społeczno-gospodarczej mieszkańców. Opisany przykład programu foresightu realizowanego w Japonii i osiągniętych tam efektów, w szczególności model „4k+z”,wskazuje na potencjał zastosowania foresightu w wymiarze regionalnym.

Wdrożenie foresightu regionalnego, będącego narzędziem oddziaływania społeczności na politykę regionalną, daje możliwość partycypacji w procesach decyzyjnych i wzmacnia poczucie 
odpowiedzialności za rozwój regionu. Ponadto służy budowie wspólnej wizji przyszłości i integruje liderów środowiskowych oraz usprawnia komunikację. Przeprowadzone dyskusje oraz badania wskazują, że kształtowanie kultury kooperacji i myślenia o przyszłości okazuje się podstawowym warunkiem rozwoju społeczno-gospodarczego regionu. Zatem stosowanie koncepcji foresight na terenie województwa zachodniopomorskiego może w konsekwencji sprzyjać dynamizacji procesów rozwojowych.

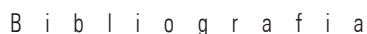

Bembenek B. (2006) Wokół koncepcji współdziałania. W: Górzyński M. (red.), System wspierania gron przedsiębiorczości - publikacja podsumowująca. Studia Europejskie, nr 5.

Borodako K. (2009) Foresight w zarzq̨dzaniu strategicznym. Warszawa: Wydawnictwo C.H. Beck.

Cuhls K. (2001) Foresight with Delphi Surveys in Japan. Technology Analysis \& Strategic Management, Vol. 14, No. 4.

Da Costa O., Warnke, P., Cagnin, C., Scapolo, F. (maj 2008) The impact of foresight on policy-making: insights from the forlearn mutual learning process. Technology Analysis \& Strategic Management, Vol. 20, No. 3.

Foresight technologiczny (2005) tom 1, Wiedeń, PARP, UNIDO. http://cordis.europa.eu/foresight/definition.htm.

HLEG-Report: Thinking, Debating and Shaping the Future, Final Report from a High Level Expert Group for the European Commission, 26 kwietnia 2002, http://www.cordis.lu/foresight/CGRF.pdf.

Jasiński L.J. (2007) Treść i przykłady badań typu foresight. Warszawa: Instytut Nauk Ekonomicznych PAN.

Kaleta A., Moszkowicz K. (2006) Plan operacyjny foresight. Projekt badawczy: priorytetowe technologie dla zrównoważonego rozwoju województwa podkarpackiego. Rzeszów: Politechnika Rzeszowska.

Karube I. (2001) Integration on Socio-economic Needs into Technology Foresight. NISTEP Study Material, nr 77.
Kuciński J. (2010) Organizacja i prowadzenie projektów foresight $w$ świetle doświadczeń międzynarodowych. Warszawa: IPPT PAN.

Kudłacz T. (1999) Programowanie rozwoju regionalnego. Warszawa: Wydawnictwo Naukowe PWN.

Kuwahara T. (2002) Technology Foresight In Japan. The Potential and Implications of Delphi Approach. NISTEP Study Material, nr 77.

Lozano Platonoff A., Gadomska-Lila K., Pachciarek H. (2009) Porównanie metod zarządzania relacjami w otoczeniu organizacji. W: Kiełtyka L. (red.), Multimedia $w$ biznesie i zarzq̨dzaniu. Warszawa: Difin.

Miles I., Keenan M. (2002) Practical Guide to Regional Foresight in the United Kingdom. Bruksela: European Commission.

Sandkjaer Hanssen G., Johnstad T., Erling Klausen J. (2009) Regional Foresight, Modes of Governance and Democracy. European Planning Studies, Vol. 17, No. 12.

Stawasz D. (2004) Ekonomiczno-organizacyjne uwarunkowania rozwoju regionu - teoria i praktyka. Łódź: Wydawnictwo Uniwersytetu Łódzkiego.

Yoda T. (2008) Participants looking back: what are perceptions of participants of past foresight activities on the impact on policy-making?, Third International Seville Seminar on Future-Oriented Technology Analysis: Impacts and implications for policy and decision-making, Sewilla 16-17 października 2008. 